\title{
PENGARUH EARNINGS MANAGEMENT DAN GOOD CORPORATE GOVERNANCE TERHADAP EXPENSE STICKINESS
}

\author{
Hari Hananto \\ Universitas Surabaya, Indonesia \\ hananto@staff.ubaya.ac.id
}

Diterima 6 April 2021

Disetujui 13 Juni 2021

\begin{abstract}
Expense stickiness is the thickness of the charge showed a response asymmetric load behavior towards a change in activity, ie when the activity decreases the burden will decline more slowly than when the activity increases. If a company's activity has decreased but also followed the rapid decline in the cost, also has been called Decrease expense stickiness, researchers predict there are motivation of management to manage earnings. The existence of good corporate governance, that with good corporate governance activities of companies that declined to follow a decreasing cost also for their efficiency on costs. It was concluded that good corporate governance also affects decreasing expense stickiness, although not as strong earnings management.The purpose of this study was to examine the pattern of expense stickiness whether companies in Indonesia tend to earnings management or good corporate governance to increase corporate profits. The population used in this study are all non-financial entities listed on the Indonesia Stock Exchange (BEI) in the period 20142015. To see the effect of earnings management to use variable expense stickiness total log administration and operational expense (SGA). As for the influence of good corporate governance to use variable expense stickiness total log administration and operational expense (SGA) or the FACT which is a variable of good corporate governance. The results of this study found that companies using earnings management do not lower the expense stickiness. This shows that company management directs the achievement of performance through real activities management rather than just accrual recognition of performance. As for good corporate governance tends to decrease the stickiness expense, prove that GCG is able to oversee management activities in managing the company. Asymmetric/ opportunistic management actions can be reduced through the effectiveness of the GCG mechanism.
\end{abstract}

Keywords: Corporate Governance; Earnings Management; Expense Stickiness.

\section{PENDAHULUAN}

\subsection{Latar Belakang}

Laporan keuangan berisi informasi yang berguna bagi pengguna laporan keuangan dalam mengetahui kinerja perusahaan yang dapat mempengaruhi pengambilan keputusan. Diantara informasi dalam laporan keuangan, nilai laba adalah salah satu focus bagi pengambil keputusan, yang oleh karenanya sering menjadi alasan pihak manajemen melakukan rekayasa laba. Pihak manajemen sering kali melakukan rekayasa pada laba suatu perusahaan sehingga kinerja perusahaan dinilai baik. Tindakan opportunistic manajemen tersebut diperoleh dengan melakukan pemilihan kebijakan akuntansi yang sesuai hasil yang diinginkan. Tindakan melalui dengan usaha rekayasa pelaporan melalui penerapan metode akuntansi tidak jarang dilakukan demi pencapaian laba memuaskan manajemen. 
Beberapa kasus tentang usaha melaporkan kinerja yang baik diantaranya terjadi pada perusahaan PT Kimia Farma, PT Indofarma, dan PT Ades Alfindo (Sulistiawan et al., 2011) dimana terjadi adanya overstated penjualan pada unit industri bahan baku, persediaan barang pada unit logistik sentral, persediaan barang dagangan, dan pada penjualan. Temuan tersebut diketahui setelah pada tahun 2004 manajemen baru mengetahui adanya inkonsistensi pengakuan penjualan periode 2001 hingga 2004 dengan tujuan memberikan informasi laba yang lebih tinggi.

Expense stickiness menjadi salah satu alat untuk mendeteksi adanya earnings management. Istilah "stickiness" menunjukkan respon perilaku beban asimetris ke arah perubahan dalam melakukan aktivitas, yaitu apabila aktivitas penjualan menurun maka beban akan menurun lebih lambat daripada saat aktivitas penjualan meningkat (Noreen dan Soderstrom, 1997), (Cooper dan Kaplan, 1998), dan (Anderson et al., 2003). Dengan demikian maka, pada umumnya, apabila tingkat aktivitas penjualan perusahaan menurun, maka beban operasional perusahaan tidak akan menurun secepat saat aktivitas penjualan itu meningkat. Sehingga apabila tingkat aktivitas penjualan perusahaan menurun diikuti dengan beban yang menurun juga, yang artinya tidak sesuai dengan konsep expense stickiness, dapat dikatakan ada usaha rekayasa yang dilakukan pihak manajemen dalam usaha untuk melaporkan laba yang tidak buruk. Ketika tingkat aktivitas penjualan perusahaan menurun, manager termotivasi untuk melakukan manajemen laba dengan mengecilkan beban operasional perusahaan sehingga laba perusahaan masih terlihat baik. Kondisi tersebut muncul pada kasus yang menimpa Jiwasraya yang diindikasikan kurang mencatatkan beban cadangan dan tidak mengakui kerugian potensial akibat gagal investasi. Deteksi earnings management melalui pola asimetris beban juga muncul pada kasus yang terjadi pada Perusahaan Listrik Negara (PLN) yang mana laporan keuangannya menunjukkan adanya ketidakseimbangan antara kenaikan pendapatan dengan beban operasional dan rugi selisih kurs. PLN melakukan pengakuan pendapatan dari berbagai sumber untuk menutupi kenaikan beban operasional (kenaikan harga energy primer) dan kerugian kurs (akibat pelemahan nilai rupiah), untuk dapat melaporkan laba yang menjanjikan. Auditor melihat adanya ketidakseimbangan antara pendapatan dan beban (expense stickiness) tersebut sebagai warning adanya manajemen laba.

Berdasarkan penelitian sebelumnya mengenai expense stickiness pada penyesuaian beban dan ekspektasi manajemen menyatakan bahwa penyesuaian beban untuk mengurangi input saat aktivitas menurun lebih tinggi daripada menaikan input saat aktivitas tinggi (Jaramillo et al., 1993, Pfann and Palm,1993, 1997, Goux et al., 2001, and Cooper and Haltiwanger, 2006). Kondisi tersebut ternyata dikarenakan manager lebih mempunyai sikap optimis mengenai pendapatan di masa yang akan datang, dimana pada umumnya perusahaan akan mengalami peningkatan pendapatan pada tahun berikutnya, sehingga manager enggan untuk mengurangi beban. Hal ini menunjukkan bahwa tidak berlakunya/tidak sesuai dengan konsep expense stickiness bukan karena ada usaha rekayasa melainkan ekspektasi manajer. Sebaliknya penelitian Dierynck dan Renders (2009) yang meneliti mengenai earnings management terhadap expense stickiness melalui beban tenaga kerja, melaporkan hasil ROA yang kecil dan positif, dan sedikit peningkatan pendapatan. Kama dan Weiss (2010), memberikan bukti bahwa perusahaan mengurangi stickiness dari beban operasi untuk menghindari kerugian dan penurunan laba. Dimana hal ini menunjukkan bahwa terjadi usaha menghindari kerugian atau penurunan laba dengan melakukan penurunan beban (konsep stickiness dilanggar). Sehingga dapat dikatakan bila konsep expense stickiness dilanggar terbukti menunjukkan adanya usaha melakukan manajemen laba. 
Wardhani dan Joseph (2010), menjelaskan bahwa usaha untuk mengurangi manajemen laba yang oportunis dapat dicapai bila tata kelola perusahaan berjalan dengan baik (good corporate governance). KNKG 2006 (Komite Nasional Kebijakan Governance) memberikan pedoman bahwa tercapainya good corporate governance pada perushaan bisa terjadi bila terdapat transparansi, akuntabilitas, responsibilitas, independensi serta kewajaran dan kesetaraan. Kesemuanya itu diperlukan agar kesinambungan usaha (sustainability) perusahaan tercapai dengan selalu memperhatikan pihak yang berkepentingan (stakeholders).

Dari sisi kesetaraan, peneliti menemukan bahwa good corporate governance juga mempengaruhi expense stickiness dimana saat tingkat aktivitas penjualan perusahaan menurun, maka manager, yang berada pada perusahaan dengan good corporate governance, akan berusaha melakukan efisiensi operasional perusahaan sehingga laba perusahaan wajar. Namun yang perlu menjadi perhatian adalah penurunan beban sebagai usaha efisiensi tersebut, dimana sesuai dengan konsep expense stickiness maka penurunan aktivitas tidak dikuti dengan penurunan efisiensi (penurunan beban) pada tingkat yang sama. Disinilah peran $G C G$ yaitu mendorong terjadinya efisiensi melalui mekanisme pengawasan yang efektif. Bila perusahaan berada pada tata kelola yang kurang baik maka manajemen mempertahankan beban dengan berdasarkan ekspektasi yang mereka harapkan (expense stickiness) atau tidak berusaha untuk melakukan upaya untuk merubah kebijakan yang sebelumnya telah ditetapkan berdasarkan ekspektasi tersebut. Pada kondisi yang lain, pada saat tingkat aktivitas penjualan meningkat, tentunya akan diikuti dengan peningkatan beban. Namun bila ditemukan adanya kondisi yang asymmetry (decrease expense stickiness) maka perusahaan yang memiliki GCG yang baik akan melihat hal tersebut sebgai usaha untuk mempertahankan laba (mungkin karena peningkatan aktivitas penjualan tidak terlalu besar) atau meningkatkan laba guna tujuan tertentu.

Setiap perusahaan listing memiliki tujuan untuk menginformasikan kinerja yang memuaskan kepada para investor maupun pihak eksternal, dimana kinerja tersebut terfokus pada pencapaian laba yang tinggi. Reaksi investor terhadap informasi laba yang tinggi adalah cenderung mengambil keputusan untuk berinvestasi pada perusahaan tersebut. Kondisi itulah yang diharapkan oleh manjemen perusahaan sehingga melakukan berbagai upaya untuk mewujudkan nilai laba yang maksimal, yaitu dengan melakukan manajemen laba. Cara yang digunakan para manajemen dalam praktik manajemen laba bermacam-macam yang disesuaikan dengan suatu kondisi perusahaan, diantaranya adalah dengan mengelola beban. Pengelolaan yang baik terhadap tentunya akan berdampak pada perolehan laba yang maksimal. Namun yang harus diperhatikan adalah apakah informasi beban yang dilaporkan oleh manajemen merupakan wujud dari pengelolaan yang sesunguhnya berdasarkan konsep expense stickiness.

Sama halnya dengan good corporate governance yang diharapkan dapat meningkatkan nilai tambah suatu perusahaan. Good corporate governance diharapkan dapat mengendalikan tindakan manajemen yang opportunistic melalui konsep expense stickiness. Pengungkapan laba yang diikuti dengan decrease expense stickiness (melanggar konsep expense stickiness) tentunya menghasilkan laporang yang kurang dapat dipertanggungjawabkan. Decrease expense stickiness digunakan agar perusahaan dapat merepresentasikan laba yang tinggi agar dapat menarik perhatian investor untuk berinvestasi pada perusahaan tersebut.

Penelitian-penelitian sebelumnya terhadap permasalahan diatas telah dilakukan dengan sampel data perusahaan di Cina (Xue et. al. 2015) yang menyimpulkan bahwa terdapat control terhadap beban pada perusahaan yang melakukan manajemen laba dan $G C G$ terbukti mampu menurunkan expense stickiness melalui pengawasan utnuk melakukan 
efisiensi sehingga kinerja perusahaan menjadi baik. Dierynck dan Renders (2009), mengamati stickiness dari beban tenaga kerja di perusahaan-perusahaan yang melaporkan hasil ROA yang kecil dan positif, dan sedikit peningkatan pendapatan. Kama dan Weiss (2010), memberikan bukti bahwa perusahaan mengurangi stickiness dari beban operasi untuk menghindari kerugian dan penurunan laba. Hasil penelitian menunjukkan bahwa expense stickiness melalui penyesuaian beban dilakukan untuk mengurangi input saat aktivitas menurun lebih tinggi daripada menaikan input saat aktivitas tinggi (Jaramillo et al., 1993, Pfann and Palm,1993, 1997, Goux et al., 2001, and Cooper and Haltiwanger, 2006). Berdasarakan hasil penelitian tersebut diatas, yang kesemuannya menggunakan data perusahaan di luar Indonesia, maka penelitian ini ingin melihat pengaruh antara earning management dan corporate governance terhadap perilaku expense stickiness pada sampel data di Indonesia. Kondisi Indonesia yang memiliki tingkat penerapan $G C G$ dan standar akuntansi yang berbeda tentunya akan melengkapi hasil kajian tentang pola asimetri dari beban dalam melihat adanya indikasi manajemen laba.

\subsection{Rumusan Masalah}

Berdasarakan hasil penelitian tersebut diatas, yang kesemuannya menggunakan data perusahaan di luar Indonesia, sementara kondisi Indonesia tentunya memiliki tingkat penerapan $G C G$ dan standar akuntansi yang berbeda maka rumusan masalah penelitian ini adalah: Apakah earning management dan corporate governance berpengaruh terhadap perilaku expense stickiness

\subsection{Telaah Literatur Dan Hipotesis \\ 1.3.1 Agency Theory}

Agency theory menyebutkan bahwa terdapat kontrak antara manajer (agent) dengan pemilik perusahaan (principal) dalam mengelola sebuah perusahaan(Jensen dan Meckling, 1976). Dengan kondisi tersebut maka principle berusaha untuk memperoleh berbagai informasi tentang kinerja manajer (agen) Penilaian principle terhadap kinerja yang baik tersebut membuat para manajer berupaya keras untuk menunjukkannya. Konflik terjadi saat terjadi ketidakselarasan kepentingan antara agents dengan principles.yang dikenal dengan asymmetry information. Manajer memiliki lebih banyak informasi mengenai tentang kondisi perushanan sekaligus kinerja mereka sesungguhnya. Dengan kondisi tersebut, bisa dimungkinkan principle tidak dapat mengetahui sesungguhnya tentang kinerja, apabila manajer melakukan usaha-usaha untuk menutupi kekurangan kinerjanya. Agen yang lebih mengenal lebih baik tentang kinerja diri, lingkungan kerja dan perusahaan secara keseluruhan dapat memberikan informasi yang berbeda dengan keadaan sesungguhnya kepada pemilik (Widyaningdyah, 2001). Bila yang dilakukan manajer tersebut berkelanjutan, maka akan merugikan perusahaan secara keseluruhan.

Dengan pertimbangan tersebut maka principle berusaha semaksimal mungkin untuk memperoleh informasi atau sinyal terhadap yang dilakukan oleh manajer sehinga sekaligus dapat mengetahui kinerja manajer. Salah satu yang menjadi perhatian adalah tindakan majemen laba.

\subsubsection{Expense Stickiness}

Noreen dan Soderstrom, 1997, Cooper dan Kaplan, 1998, dan Anderson et al., 2003, menyatakan bahwa expense stickiness merupakan respon perilaku beban asimetris ke arah perubahan dalam melakukan aktivitas. Secara umum, bila terdapat kenaikan aktivitas maka akan diikuti oleh kenaikan beban namun tidak demikian saat terjadi penurunan aktivitas 
dimana beban tidak menurun secepat penuruna aktivitas. Sehingga dapat dikatakan beban meningkat lebih cepat dengan meningkatnya aktivitas penjualan daripada saat beban menurun dengan penurunan aktivitas penjualan. Artinya apabila suatu perusahaan mengalami peningkatan aktivitas penjualan maka beban juga akan mengalami peningkatan, tetapi sebaliknya apabila aktivitas penjualan perusahaan mengalami penurunan maka beban mengalami penurunan lebih lambat daripada saat aktivitas penjualan itu meningkat.

Kondisi beban asimetri terjadi bila penurunan aktivitas penjualan perusahaan diikuti dengan beban yang menurun dengan cepat ini disebut sebagai decrease expense stickiness. Penurunan beban ini disinyalir sebagai usaha untuk mempertahankan laba pada saat penurunan aktivitas. Manajer melakukan upaya untuk mengatur beban guna menghasilkan laba yang menjanjikan atau mempertahankan laba di saat menghadpi masa yang sulit. Dengan demikian bila ditemukan adanya decrease expense stickiness dapat memberikan sinyal bahwa terdapat usaha manajer melakukan manajemen laba.

\subsubsection{Managemen Laba (earnings management)}

Manajemen laba sebagai suatu proses pengambilan langkah dengan adanya unsur kesengajaan yang sesuai dengan kebijakan prinsip akuntansi yaitu General Accepted Accounting Princip (GAAP) maupun tidak. Manajemen laba merupakan pemilihan kebijakan akuntansi oleh manajer, atau tindakan yang dapat mempengaruhi laba, yang bertujuan untuk mencapai beberapa tujuan dalam pelaporan laba (Scott, 2015). Para manajer melakukan manajemen laba dilakukan dengan cara memanfaatkan fleksibilitas yang diperbolehkan dalam Prinsip-prinsip Akuntansi yang Berlaku Umum (PABU) dimana terdapat beberapa metode akuntansi berkaitan dengan informasi laba. Berdasarkan itu, manajer dapat melakukan abusive earnings management untuk menghasilkan informasi laba sesuai dengan keinginan atau target yang diharapkan.

Salah satu motivasi manajemen laba adalah memaksimalisasikan pendapatan masa kini atau tahun berjalan yang menjadi target para manajer (Scott,2015) Ketika target manajer belum tercapai maka manajer akan berusaha untuk melakukan berbagai usaha agar bonus tetap mereka dapatkan atau kinerja mereka tidak terlihat menurun. Disamping untuk mengamankan kinerja manajer, motivasi melakukan manajemen laba juga terkait dengan hubungannya dengan pihak luar perusahaan, diantaranya adalah usaha dalam mempertahankan nilai perusahaan sehingga tidak melanggar kesepakatan kontrak, mengurangi biaya politik, mengatur pemenuhan pembayaran kewajiban pajak, atau sebagai usaha menaikkan nilai perusahaan pada saat penawaran saham.

Manajemen laba memungkinkan untuk melakukan penghindaran pelaporan kerugian pada laporan keuangan, mengurangi pajak, dan sebagainya. Scott (2015),menyebutkan bahwa ada salah satu bentuk usaha bentuk manajemen laba adalah income maximization. Menurut Burgstahler dan Dichev (1997) dan Degeorge et al. (1999), menemukan bahwa manajemen laba membantu dalam menghindari pelaporan kerugian dan penurunan laba pada laporan keuangan. Roychowdhury (2006) dan Cohen et al. (2008), menyatakan bahwa adanya 2 kategori dalam earnings management yaitu small positive profit dan small earning increase. Menurut (Carslaw, 1988: Thomas, 1989), menyatakan bahwa perusahaan menerapkan kebijakan untuk meningkatkan penghasilan ketika peningkatan pendapatannya sedikit dibawah angka 0. Sama halnya dengan cara meningkatkan laba yang kecil padahal laba perusahaan mengalami penurunan, dimana perusahaan lebih cenderung menaikkan laba sekecil mungkin daripada laba terlihat menurun. Sehingga dapat disimpulkan bahwa manajemen laba dilakukan untuk menghindari kerugian atau membuat laba terlihat baik agar melebihi ekspektasi investor. Menurut Barefield dan Comiskey, (1975), dan Barefield dan 
Comiskey (1975 ); Brown, (1997) ; Richardson et al, (1999), memperkirakan bahwa rata-rata perusahaan besar dan kecil cenderung untuk melebih-lebihkan laba dengan maksud untuk memberikan ledakan yang lebih dari ekspektasi investor.

Perolehan laba yang maksimal dapat dilakukan dengan pengakuan pendapatan semaksimal mungkin maupun penurunan beban semaksimal mungkin. Roychowdhury (2006) dan Cohen et al. (2008), menyatakan bahwa manajemen akan mengurangi beban untuk menghindari kerugian atau penurunan pada laporan keuangan. Terkait dengan pengurangan beban, terdapat perilaku yang menjadi perhatian peneliti yang kemudian dikenal dengan decrease expense stickiness. Kondisi tersebut terjadi saat terjadinya peningkatan aktivitas perusahaan yang tidak diikuti dengan peningkatan beban. Menurut Noreen dan Soderstrom, 1997, Cooper dan Kaplan, 1998, dan Anderson et al., 2003, menyatakan bahwa expense stickiness merupakan respon perilaku beban asimetris ke arah perubahan dalam melakukan aktivitas, yaitu beban meningkat lebih cepat dengan meningkatnya aktivitas daripada saat beban menurun seiring dengan penurunan aktivitas. Apabila peningkatan aktivitas penjualan perusahaan yang tidak diikuti dengan beban yang meningkat maka terjadilah yang disebut sebagai decrease expense stickiness. Decrease expense stickiness ini merupakan peningkatan aktivitas penjualan perusahaan yang tidak diikuti dengan beban yang meningkat.

Peneliti melihat bahwa bila terjadi peningkatan aktivitas perusahaan yang tidak diikuti dengan beban yang meningkat mengindikasikan adanya earnings management, yaitu usaha untuk melaporkan laba yang besar. Peningkatan penjualan aktivitas perusahaan yang tidak diikuti dengan peningkatan beban menunjukkan kemungkinan adanya motivasi manajer untuk melakukan manajemen laba (Shuang Xue dan Yun Hong, 2015). Dengan demikian maka munculnya decrease expense stickiness dipengaruhi oleh usaha manajemen dalam menghasilkan laba yang meningkat melalui earning management. Oleh karena itu dapat dikatakan bahwa meningkatnya manajemen laba signifikan mempengaruhi munculnya decrease expense stickiness.

$\mathbf{H}_{1}$ : Earnings management melalui peningkatan profit cenderung menurunkan expense stickiness.

\subsubsection{Good Corporate Governance (GCG)}

Forum for Corporate Governance in Indonesia (FCGI, 2001) menyatakan bahwa corporate governance adalah seperangkat peraturan yang mengatur hubungan antara pihakpihak yang berkepentingan terhadap perusahaan, baik internal maupun eksternal, dalam pengelolaan dan pengendalian perusahaan. Good Corporate Governance (FCGI, 2001) mengarahkan pengelolaan perusahaan demi tercapainya fairness, transparency, accountability, responsibility sehingga perusahaan berjalan sesuai ketentuan dan terhindar dari penyalahgunaan kekuasaan serta selalu menjunjung etika bisnis serta selalu menjaga lingkungan bisnis yang sehat. Kondisi ini bisa terjadi bila terdapat prosedur/mekanisme dan hubungan yang baik antara pengelola perusahaan dengan pihak pengawas/pengontrol dalam segala pengambilan putusan yang penting.

Menurut Iskander \& Chamlou (2000), pelaksanaan good corporate governance dapat dilakukan secara internal dan external mechanisms. Internal mechanisms dilakukan dengan mengendalikan perusahaan melalui pengawasan dengan menggunakan struktur dan proses internal perusahaan seperti rapat umum pemegang saham (RUPS), komposisi dewan direksi, komposisi dewan komisaris dan pertemuan dengan board of director. Sedangkan external mechanisms dilakukan dengan cara mengawasi perusahaan melalui keterlibatan peran pengendalian oleh perusahaan lain dalam mekanisme pengawasan. Disamping itu, pengawasan eksternal juga dapat diperoleh melalui dengan serta pengendalian pasar. 
Pemegang saham (pemilik) yang berada pada jajaran manajemen merupakan kondisi yang menunjang berjalanya good corporate governance dimana mereka dapat terlibat dan menuntut laporan keuangan yang akurat. Demikian juga dengan adanya dewan komisaris yang berperan sebagai pengawasan, dimana komposisi dewan komisaris yang tepat dapat menekan pihak manajemen untuk menyusun laporan keuangan yang baik (Boediono, 2005). Peran dewan komisaris dalam mengawasi pengelolaan perusahaan ditentukan oleh ketepatan komposisi dan efektifitas rapat pengawasan (Lipton dan Lorsch,1992, dan Yatim et al, 2006) Keberadaan komite audit, dengan proses auditnya, akan berperan dalam terbitnya laporan keuangan yang kredibel, yang tentunya akan dapat menghambat manajemen untuk melakukan untuk tindakan oppportunistic demi kepentingan sendiri (Andri dan Hanung, 2007).

Dengan melihat uraian di atas tampak bahwa peran $G C G$ adalah dalam usaha untuk memuaskan para shareholders terhadap informasi tentang kinerja perusahaan. Shareholder value dan dividen yang memuaskan adalah hasil dari informasi kinerja perusahaan yang baik. Informasi kinerja yang kurang baik biasanya tidak akan bertahan lama dan malah berakibat buruk bagi kesinambungan perusahaan. Adalah menjadi tugas perusahaan untuk membuat mekanisme $G C G$ yang efektif agar hal tersebut dapat dicapai. $G C G$ harus mampu menciptakan mekanisme yang tepat dan efektif guna mengurangi tindakan-tindakan oportunistik dari para pengelola (manajemen).

Menurut Shuang Xue dan Yun Hong, 2015, good corporate governance memiliki hubungan dengan expense stickiness. Menurut Noreen dan Soderstrom, 1997, Cooper dan Kaplan, 1998, dan Anderson et al., 2003, menyatakan bahwa expense stickiness merupakan respon perilaku beban asimetris ke arah perubahan dalam melakukan aktivitas, yaitu beban meningkat lebih cepat dengan meningkatnya aktivitas daripada saat beban menurun dengan penurunan aktivitas. Artinya apabila suatu perusahaan mengalami peningkatan aktivitas maka beban juga akan mengalami peningkatan, tetapi sebaliknya apabila aktivitas perusahaan mengalami penurunan maka beban juga akan mengalami penurunan. Tetapi apabila peningkatan aktivitas perusahaan yang tidak diikuti dengan beban yang meningkat maka ini disebut sebagai decrease expense stickiness. Beberapa peneliti menyimpulkan bahwa good corporate governance $(G C G)$ akan mempengaruhi munculnya decrease expense stickiness. Decrease expense stickiness disini diartikan bahwa dengan good corporate governance perusahaan cenderung untuk melakukan efisiensi beban. $G C G$ yang baik akan mampu memonitor/mengawasi tindakan manejemen khususnya saat Oleh karena itu tata kelola perusahaan yang baik secara signifikan mempengaruhi decrease expense stickinesss (Shuang Xue dan Yun Hong, 2015).

Menurut (Muntoro, 2011), dewan komisaris memiliki andil dalam terciptanya good corporate governance. Efektifitas peran dewan komisaris ditentukan oleh beberapa hal diantaranya adalah rutinitas rapat, dan adanya proporsi dewan komisaris independen. Menurut (Lipton dan Lorsch,1992, dan Yatim et al, 2006) menyatakan bahwa frekuensi rapat yang tepat dari dewan komisaris akan memudahkan dalam mendapat informasi mengenai perkembangan perusahaan, yang sekaligus menjadi kajian dalam pengawasan lebih lanjut. Menurut Machfoedd'z, (2006), proporsi dewan komisaris independen yang tepat dapat menciptakan praktek good corporate governance yang diperoleh melalui obyektifitas mereka dalam menilai kinerja perusahaan.

$\mathbf{H}_{2}$ : Tata kelola perusahaan yang baik cenderung menurunkan expense stickiness. 


\subsection{Model Penelitian}

Hipotesis 1

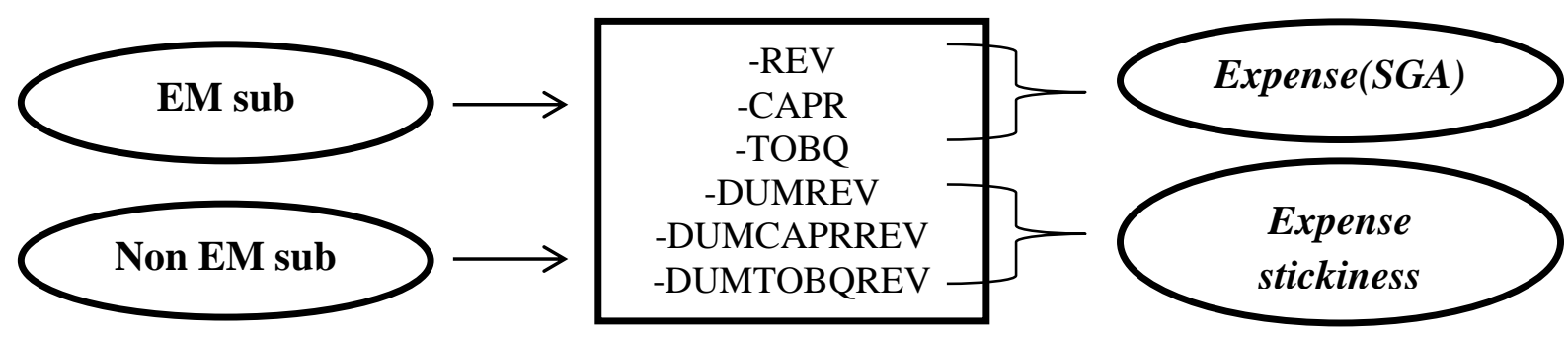

Hipotesis 2

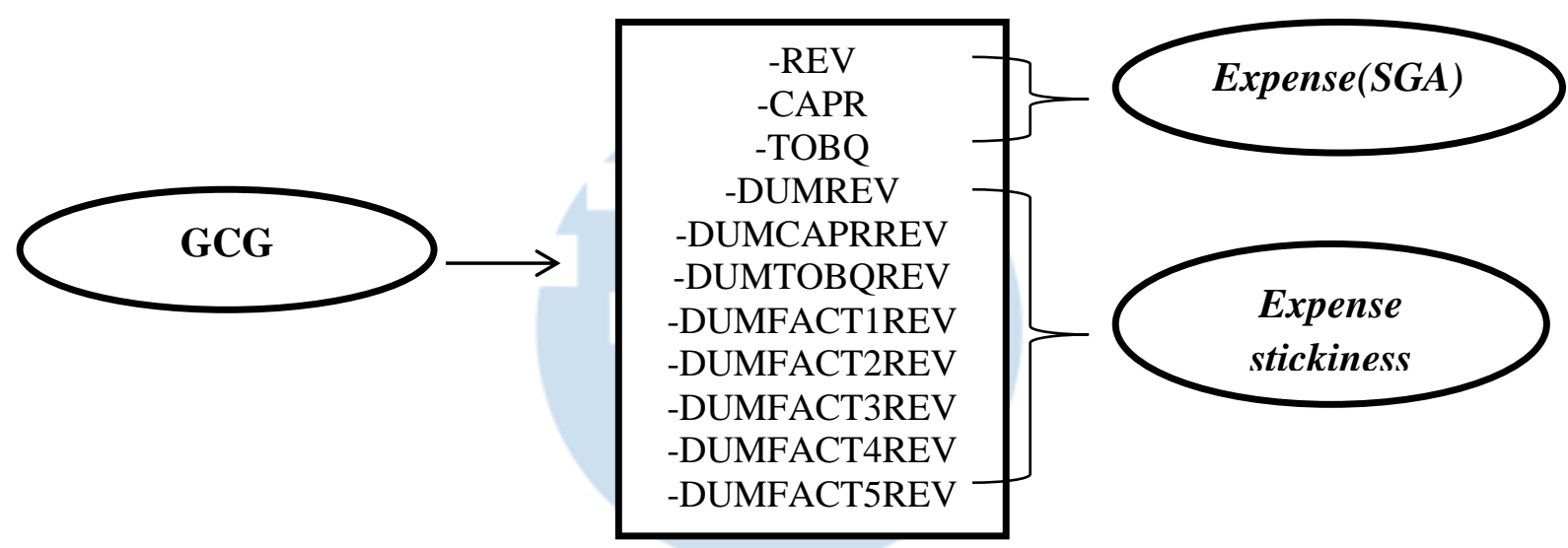

Gambar 1. Model Penelitian

\section{METODOLOGI DAN ANALISIS DATA}

\subsection{Gambaran Umum Objek Penelitian}

Obyek data penelitian yang digunakan dalam penelitian ini adalah seluruh perusahaan go public non keuangan yang terdaftar di Bursa Efek Indonesia pada periode tahun 2014 sampai 2015, melalui laporan keuangan teraudit untuk periode yang berakhir 31 Desember 2014-31 Desember 2015.

\subsection{Metode Penelitian}

Metode penelitian yang dipakai dalam penelitian ini adalah causal study. Penelitian ini ingin menguji apakah terdapat hubungan antara variabel independen, yaitu partisipasi pengguna, program pelatihan dan pendidikan bagi pengguna SIA, dukungan manajemen puncak, formalisasi pengembangan SIA dan kecanggihan teknologi informasi terhadap variabel dependen yaitu kinerja SIA. Desain riset yang digunakan adalah riset eksplanatif dengan pendekatan hypotetico deductive, yaitu metode penelitian yang melibatkan pengujian hipotesis yang dideduksi dari hipotesis lainnya yang tingkat abstraksinya atau perumusan konseptualnya lebih tinggi (Wallace, 1971).

\subsection{Penelitian}




\subsubsection{Variabel Dependen}

Variabel dependen untuk kedua hipotesis pada penelitian ini adalah adalah expense stickiness yang dihitung dengan menggunakan model yang mengacu kepada model Anderson et al.,2003; Subramaniam and Weidenmier,2003.

$$
\log \left[\frac{S G A i_{2} t}{S G A i_{2} t-1}\right]=\text { proksi beban akrual untuk menunjukkan expense stickiness. }
$$

$S G A=$ logaritma dari total administration and operation expenses

Bila mengalami penurunan maka menunjukkan terdapat usaha dari manajemen untuk melakukan manajemen laba melalui penurunan beban akrual.

\subsubsection{Variabel Independen}

\section{Manajemen Laba}

Data penelitian akan dibagi menjadi dua sub sample, yaitu sampel data perusahaan yang melkukan manajemen laba dan yang tidak melakukan manajemen laba. Penentukan adanya earnings management dan non-earnings management dilakukan dengan melihat ROA dan perubahan laba. Perusahaan yang memiliki ROA 0-1,5\% yang diartikan sebagai small positive profit sub-sample. Perusahaan yang memiliki nilai antara $0-1 \%$, dari hasil perubahan laba yang dibagi dengan total asset, dikategorikan sebagai small earnings increase sub-sample. ROA dan perubahan laba yang kecil dapat mengindikasikan adanya penghindaran pelaporan kerugian atau penghindaran untuk melaporkan penurunan laba pada laporan keuangan perusahaan. Oleh karena itu maka perusahaan yang termasuk kategori small positive profit atau small earnings increase dikategorikan sebagai kelompok perusahaan yang melakukan earnings management (Earnings Management sub sample) sebaliknya perusahaan yang tidak masuk dalam sub sampel tersebut dianggap tidak melakukan earnings management (Non Earnings Management sub sample)

Variabel dummy (DUM) digunakan sebagai variable independen, yang menunjukkan kondisi revenue (REV) perusahaan

DUM = 1 jika revenue perusahaan pada tahun $\mathrm{t}$ menurun dibanding tahun sebelumnya $\left(R E V_{i, t} / R E V_{i, t-1}<1\right)$

$\mathrm{DUM}=0$ jika revenue perusahaan pada tahun $\mathrm{t}$ naik dibanding tahun sebelumnya $D U M R E V^{*} \log \left[\frac{R E V i_{2}, t}{R E V i_{2},-1}\right]=$ proksi kondisi perusahaan yang berada pada kondisi penurunan aktivitas yang nantinya menentukan pengaruhnya terhadap pola penurunan beban akrual (pola expense stickiness)

2. Good Corporate Governance (GCG)

Variabel $G C G$ pada penelitian ini terdiri dari:

FACT $1=$ presentase kepemilikan dari pemegang saham terbesar.

FACT 2 = jumlah rapat dewan komisaris per periode laporan keuangan.

FACT 3 = presentase kepemilikan saham dari institusional investor.

FACT $4=$ presentase komisaris independen dibagi dengan total komisaris.

FACT $5=$ presentase kepemilikan saham dari manajemen.

\subsection{Teknik Pengumpulan Data}

Data yang dipakai dalam penelitian adalah data sekunder yang diambil dari laporan keuangan dari seluruh perusahaan go public non keuangan teraudit yang terdaftar di Bursa Efek Indonesia pada akhir periode tahun 2014 sampai 2015. 


\subsection{Teknik Pengambilan Sampel}

Teknik pengambilan sampel yang akan dilakukan adalah dengan menggunakan metode non probability sampling yang diambil sesuai dengan kriteria kebutuhan data variable.

\subsection{Teknik Analisis Data}

Analisis data pada penelitian ini persamaan fungsi regresi linier berganda yaitu:

\section{Hipotesis 1:}

Pada hipotesis 1 ini, data akan dibagi menjadi dua sub sampel yaitu sub sampel EM (perusahaan yang diduga melakukan earnings management) dan sub sampel non EM. Pengujian H1 mengikuti permodelan Xue dan Hong (2002) sebagai berikut:

$$
\begin{aligned}
& \log \left[\frac{S G A i_{,} t}{S G A i_{2} t-1}\right]=\beta_{0+} \beta_{1} \log \left[\frac{R E V i, t}{R E V i, t-1}\right]+\beta_{2} D U M+\beta_{3} C A P R_{\mathrm{i}, t}+\beta_{4} T O B Q_{\mathrm{i}, \mathrm{t}}+ \\
& \beta_{5} D U M R E V^{*} \log \left[\frac{R E V i, t}{R E V i, t-1}\right]+\beta_{6} D U M^{*} C A P R_{\mathrm{i}, t} * \log \left[\frac{R E V i, t}{R E V i, t-1}\right]+ \\
& \beta_{7} D U M^{*} T O B Q_{\mathrm{i}, \mathrm{t}} * \log \left[\frac{R E V_{i}, \mathrm{t}}{\text { REVi, }_{2} t-1}\right]+\varepsilon_{\mathrm{i}, \mathrm{t}}
\end{aligned}
$$

Keterangan:

$\log \left[\frac{S G A i_{2} t}{S G A i_{2} t-1}\right]=$ proksi beban akrual untuk menunjukkan expense stickiness. Bila mengalami penurunan maka menunjukkan terdapat usaha dari manajemen untuk melakukan manajemen laba melalui penurunan beban akrual.

$S G A=$ logaritma dari total administration and operation expenses

$\mathrm{REV}=$ logaritma natural dari revenue

$\mathrm{DUM}=1$ jika revenue perusahaan pada tahun $\mathrm{t}$ menurun dibanding tahun sebelumnya

$\left(R E V_{i, t} / R E V_{i, t-1}<1\right)$

$\mathrm{DUM}=0$ jika revenue perusahaan pada tahun t naik dibanding tahun sebelumnya

$D U M R E V^{*} \log \left[\frac{R E V i_{0}, t}{R E V i_{0} t-1}\right]=$ proksi kondisi perusahaan yang berada pada kondisi penurunan aktivitas yang nantinya menentukan pola penurunan beban akrual.

Variabel Kontrol:

\section{1) Capital Intensity (CAPR)}

\section{2) Tobins'Q (TOBQ)}

$$
\mathrm{CAPR}=\frac{\text { Net Value of Fixed Assets }}{\text { operating Revenue }}
$$

Tobin's $\mathrm{Q}=\frac{\text { MVE+(Nilai Buku Total Aset-Nilai Buku Ekwitas) }}{\text { Nlai Buku Total Aset }}$

MVE = harga penutupan saham di akhir tahun buku kali banyaknya saham biasa yang beredar.

Nilai dari total asset dan total ekuitas berdasarkan statement of financial position.

Berdasarkan definisi expense stickiness, maka apabila nilai dari $\beta_{5}$ signifikan negatif mengindikasikan adanya eksistensi expense stickiness. Expense dikatakan sticky apabila dengan adanya penurunan revenue, expense tidak ikut turun. Dengan $\beta_{5}$ yang negatif dan signifikan artinya untuk perusahaan-perusahaan yang mengalami penurunan revenue 
(DUM=1), maka penurunan revenue tersebut tidak diikuti dengan penurunan administration and operation expenses. Sebaliknya bila ditemukan nilai signifikan positif maka terdapat usaha menurunkan beban sebagai usaha untuk mempertahankan atau menaikkan laba (earnings management)

\section{Hipotesis 2:}

Sementara $\mathbf{H}_{2}$ diuji dengan menggunakan regresi berikut, dengan mengacu pada penelitian Xue dan Hong, 2002:

$$
\begin{aligned}
& \log \left[\frac{S G A i_{2} t}{S G A i_{2} t-1}\right]=\beta_{0+} \beta_{1} \log \left[\frac{R E V i, t}{R E V i_{2}, t-1}\right]+\beta_{2} D U M+\beta_{3} D U M R E V^{*} \log \left[\frac{R E V i_{0} t}{R E V i_{2} t-1}\right]+\sum_{i=1}^{5} \beta_{i} F A C T_{\mathrm{i}, t}+ \\
& \sum_{i=1}^{5} \beta_{i} D U M^{*} F A C T_{\mathrm{i}, \mathrm{t}} * \log \left[\frac{R E V i, \mathrm{t}}{R E V i, t-1}\right]+\beta_{14} C A P R_{\mathrm{i}, \mathrm{t}}+\beta_{15} T O B Q_{\mathrm{i}, \mathrm{t}}+ \\
& \beta_{16} D U M^{*} C A P R_{\mathrm{i}, \mathrm{t}} * \log \left[\frac{R E V i, t}{R E V i, t-1}\right]+\beta_{17} D U M^{*} T O B Q_{\mathrm{i}, \mathrm{t}} * \log \left[\frac{R E V i, t}{R E V i, t-1}\right]+\varepsilon_{\mathrm{i}, \mathrm{t}}
\end{aligned}
$$

FACT adalah variabel-variabel good corparate governance yang terdiri dari:

FACT $1=$ presentase kepemilikan dari pemegang saham terbesar.

FACT 2 = jumlah rapat dewan komisaris per periode laporan keuangan.

FACT 3 = presentase kepemilikan saham dari institusional investor.

FACT $4=$ presentase komisaris independen dibagi dengan total komisaris.

FACT 5 = presentase kepemilikan saham dari manajemen.

Persamaan untuk menguji $\mathrm{H}_{2}$ dilakukan pada full sample (tidak dibagi menjadi sub sampel earnings managment dan non-earningsmanagement) $\mathrm{H}_{2}$ diterima apabila nilai $\beta_{i}$ DUMFACTREV $(i=8, \ldots, 13)$ signifikan positif karena good corporate governance menurunkan expense stickiness. Artinya, untuk perusahaan-perusahaan yang mengalami penurunan revenue (DUM=1), maka dengan adanya praktek corporate governance yang baik, expense stickiness akan berkurang. Semakin rendah revenue, maka semakin rendah pula administration and operation expenses atau terjadi decrease expense stickiness

\section{HASIL PENELITIAN DAN DISKUSI \\ 3.1 Objek Penelitian}

Objek yang digunakan dalam penelitian ini adalah seluruh perusahaan kecuali sektor keuangan dan perbankan yang terdaftar di Bursa Efek Indonesia (BEI) pada tahun 2014-2015. Obyek perusahan yang akan digunakan sebagai data adalah yang memenuhi syarat sesuai dengan seluruh kriteria variable penelitian. Bila terdapat perusahaan yang tidak memenuhi maka obyek tersebut tidak digunakan dalam penelitian. Jumlah data perusahaan pada tahun 2014 adalah sebanyak 450 sedangkan data perusahaan pada tahun 2015 adalah sebanyak 448, sehingga total data perusahaan selama tahun 2014-2015 adalah sebanyak 898. Dari populasi yang ada tersebut kemudian diseleksi sesuai dengan kriteria-kriteria yang telah ditentukan. Berikut ini akan ditampilkan tabel 1 tentang kriteria pengambilan sampel untuk objek penelitian: 
Tabel 1. Kriteria Pengambilan Sampel untuk Objek Penelitian

\begin{tabular}{|c|c|c|c|}
\hline \multirow{2}{*}{ Keterangan } & \multicolumn{3}{|c|}{ Hipotesis 1 dan 2} \\
\hline & 2014 & 2015 & Total \\
\hline $\begin{array}{l}\text { Perusahaan yang bergerak di semua sektor } \\
\text { kecuali sektor keuangan yang listing di BEI } \\
\text { tahun 2014-2015 }\end{array}$ & 450 & 448 & 898 \\
\hline Ketidaksesuaian dengan kriteria sampel : & \multirow{3}{*}{$(194)$} & \multirow{3}{*}{$(192)$} & \multirow{3}{*}{$(386)$} \\
\hline $\begin{array}{l}\text { 1. Menerbitkan laporan keuangan } \\
\text { menggunakan mata uang selain rupiah } \\
\text { (mengurangi pengaruh nilai mata uang) }\end{array}$ & & & \\
\hline $\begin{array}{l}\text { 2. Tidak memiliki ketersediaan data } \\
\text { mengenai variabel-variabel selama tahun } \\
\text { 2014-2015 (mempermudah } \\
\text { perbandingan terhadap kesimpulan) }\end{array}$ & & & \\
\hline $\begin{array}{l}\text { Total badan usaha yang menjadi objek } \\
\text { penelitian selama } 2 \text { periode }\end{array}$ & 256 & 256 & 512 \\
\hline
\end{tabular}

\subsection{Hasil dan Pembahasan}

\subsubsection{Hipotesis 1}

Hasil pengolahan data tampak pada table 2:

Tabel 2. Hasil Pengujian Regresi Linier - untuk sub-sampel EM dan non EM

\begin{tabular}{ccccc}
\hline \multirow{2}{*}{ Variabel } & \multicolumn{2}{c}{ Sub-sampel: EM } & \multicolumn{2}{c}{ Sub-sampel: non-EM } \\
\cline { 2 - 5 } & $\mathrm{B}$ & $\mathrm{T}$ & $\mathrm{B}$ & $\mathrm{t}$ \\
\hline Konstanta & 0,003 & $3,690^{* * *}$ & 0,004 & $8,773^{* * *}$ \\
REV & 0,626 & $10,304^{* * *}$ & 0,077 & $1,991^{* *}$ \\
DUM & $-0,001$ & $-0,802$ & $-0,003$ & $-3,977^{* * *}$ \\
CAPR & $-0,001$ & $-7,956^{* * *}$ & 0,000 & 1,140 \\
TOBQ & 0,00 & 0,200 & 0,00 & $-1,457^{*}$ \\
DUMREV & $\mathbf{- 0 , 4 4 4}$ & $\mathbf{- 3 , 5 4 0 * * *}$ & $-0,045$ & 0,704 \\
DUMCAPRREV & $-0,010$ & $-5,616^{* * *}$ & $-0,035$ & $-1,021$ \\
DUMTOBQREV & $-0,087$ & $-1,825^{*}$ & $-0,007$ & $-3,727 * * *$ \\
F-Test & \multicolumn{2}{c}{$20,117^{* * *}$} & \multicolumn{2}{c}{$9,160^{* * *}$} \\
Adj R ${ }^{2}$ & \multicolumn{2}{c}{0,491} & 0,153 \\
\hline
\end{tabular}

One-tail test. $*, * *, * * * \quad$ mengindikasikan signifikan pada tingkat $10 \%, 5 \%$ dan $1 \%$

- Hipotesis 1: Meningkatnya manajemen laba signifikan mempengaruhi decrease expense stickiness.

Hipotesis 1 yang diharapkan adalah bahwa koefisien DUMREV untuk sub sampel EM adalah positif (hubungan searah) sedangkan koefisien pada sub sampel Non-EM negatif signifikan. Hipotesis ini berdasarkan pemikiran bahwa saat aktivitas menurun maka proses manajemen laba (EM) akan berusaha menurunkan beban (hubungan searah) agar tetap tercipta laba.

Hasil uji parsial (t-test) hipotesis 1 pada tabel 2 dapat menunjukkan bahwa variable independen utama DUMREV, pada sub sampel EM menunjukkan negative signifikan (0,444) sedangkan pada sub sampel Non EM menunjukkan adanya pengaruh tidak signifikan 
$(-0,045)$ terhadap variable dependen. Dengan hasil tersebut (dimana koefisien sub sampel EM adalah signifikan negatif dan sub sampel Non-EM negatif tidak signifikan) maka $\mathrm{H}_{1}$ ditolak.

Nilai koefisien negatif signifikan pada sub sampel EM tersebut di atas menunjukkan hubungan negatif antara penurunan aktivitas (revenue) dengan beban, yang berarti pula bahwa pada saat perusahaan pada sub sampel EM mengalami penurunan aktivitas/penjualan maka yang terjadi adalah peningkatan beban (bukan purunan beban seperti hipotesis). Dengan demikian menunjukkan bahwa expense stickiness (beban tetap dengan polanya) tetap terjadi pada perusahaan yang melakukan EM. Sehingga dugaan perusahaan sub sampel EM melakukan manajemen laba melalui penurunan beban (decrease expense stickiness) menjadi tidak terbukti.

Kesimpulan tersebut di atas juga dipertegas dengan nilai koefisian sub sampel EM yang lebih besar daripada non-EM yang mana hal tersebut menunjukkan bahwa expense stickiness (tidak terjadi penurunan beban) pada perusahaan sub sampel EM lebih besar dari pada sub sampel non-EM. Dengan demikian maka manajemen laba, melalui penurunan beban, malah sedikit terjadi pada sub sampel perusahaan EM dibanding sub sampel non EM

\subsubsection{Hipotesis 2}

Hasil pengolahan data tampak pada table 3:

Tabel 3. Hasil Pengujian Regresi Linier Hipotesis 2

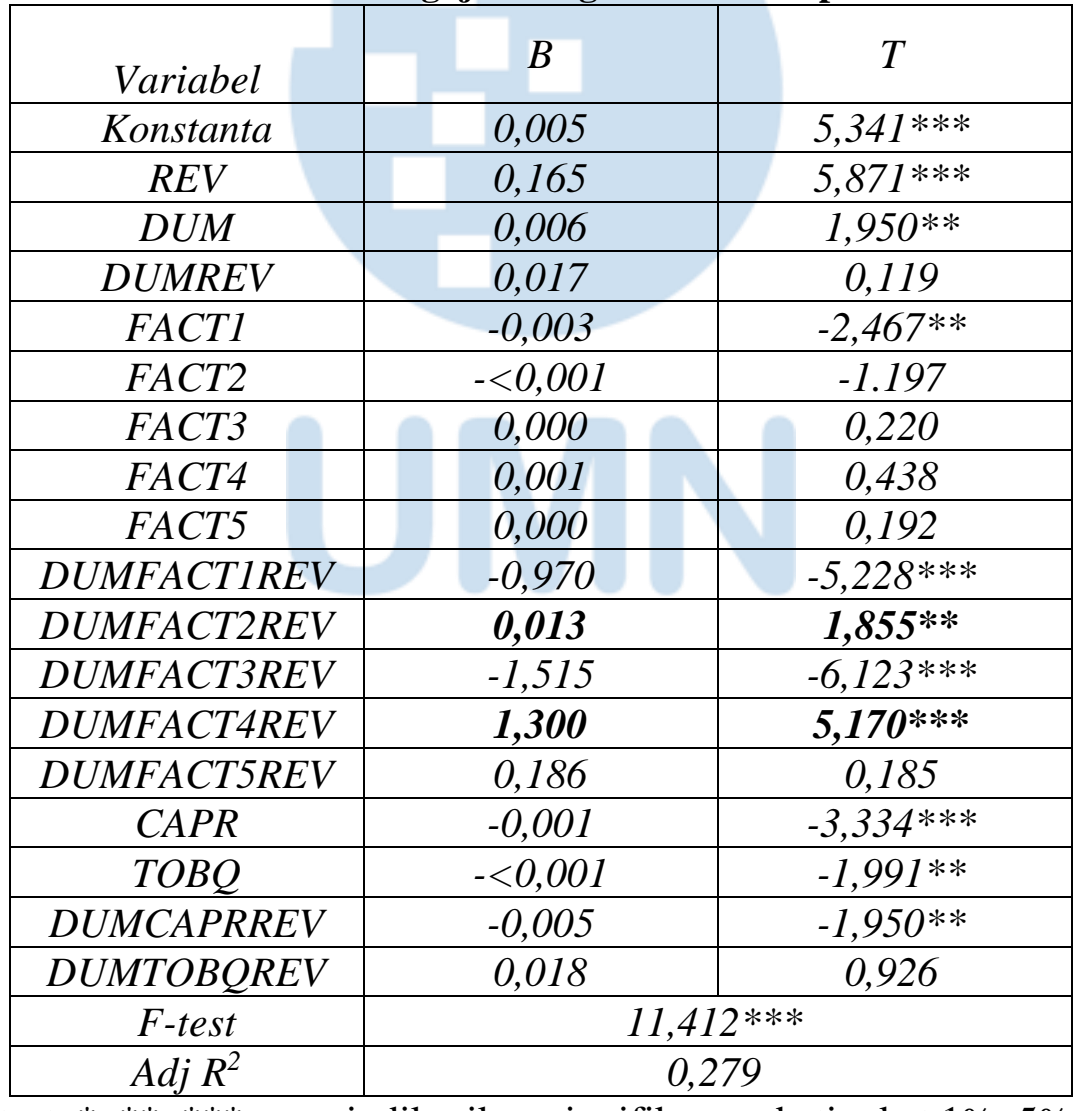

One-tail test. *, **, *** mengindikasikan signifikan pada tingkat $1 \%, 5 \%$ dan $10 \%$ 


\section{- Hipotesis 2}

$\mathrm{H}_{2}$ : Tata kelola perusahaan yang baik mempengaruhi decrease expense stickiness.

Hasil uji parsial (t-test) hipotesis 2 pada tabel 3 menunjukkan bahwa adanya kecenderungan pengaruh positif antara variabel independen utama yaitu FACT dan DUMREV terhadap variabel dependen expense stickiness. Kecenderungan variabel FACT dan DUMREV yang berpengaruh positif terhadap SGA, dapat diartikan bahwa peran mekanisme good corporate governance dilakukan secara efektif dengan cara mengefisiensikan/penurunan beban (decrease expense stickiness). Hal tersebut dapat diartikan bahwa terdapat hubungan bila aktivitas menurun maka $G C G$ akan mendorong terjadinya penurunan beban (decrease expense stickiness) sehingga diharapkan tetap dapat mencapai laba yang diharapkan.

Expense stickiness, yang merupakan keadaan dimana penurunan aktivitas penjualan yang tidak diikuti dengan penurunan biaya, tidak terjadi saat good corporate governance berperan dengan baik. Artinya dengan adanya good corporate governance, biaya yang tadinya tidak turun maka dapat diturunkan dengan cara mengefisiensikan biaya pada perusahaan tersebut (disebut sebagai decrease expense stickiness). Hal ini membuktikan bahwa tata kelola perusahaan yang baik akan menyebabkan menurunnya expense stickiness, sehingga $\mathbf{H 2}$ diterima

Hasil penelitian ini menunjukkan bahwa terdapat pengaruh secara signifikan antara DUMFACT2REV (jumlah rapat dewan komisaris) dan DUMFACT4REV (proporsi dewan komisaris independen) terhadap penurunan expense stickiness. Seperti yang disimpulkan (Lipton dan Lorsch,1992, dan Yatim et al, 2006) bahwa efektifitas rapat dewan komisaris dan proporsi dewan komisaris independen akan mempengaruhi pengawasan pelaporan keuangan. Machfoedd'z, (2006), menyatakan bahwa proporsi dewan komisaris independen dapat menciptakan good corporate governance. Dewan komisaris independen akan dapat meihat secara lebih obyektif terhadap kinerja manajemen. Obyektivitas ini akan dapat melihat dan mengevaluasi adanya expense stickiness yang tidak wajar.

Variabel good corporate governance lain yaitu DUMFACT1REV dan DUMFACT3REV menyimpulkan bahwa tidak berpengaruh. Hal tersebut berarti proporsi kepemilikan saham terbesar dan untuk investor institusional tidak dapat mempengaruhi kinerja manajemen dalam mengefisiensikan biaya pada perusahaan. Hal ini disebabkan investor institusional lebih berfokus pada laba bukan pada upaya efisiensi biaya. Kondisi tersebut dimungkinkan juga karena peran mereka tidak langsung berhubungan dengan operasioanl perusahaan.

Demikian pula halnya DUMFACT5REV, juga menunjukkan hasil yang tidak berpengaruh. pada variabel DUMFACT5REV (kepemilikan saham oleh manajemen) Hal ini mungkin disebabkan karena proporsi kepemilikan yang sangat kecil dan sangat jarang di temukan di perusahaan di Indonesia ini, sehingga tentunya perannya terhadap kendali operasional perusahan tidaklah besar.

\section{KESIMPULAN DAN SARAN}

\subsection{Kesimpulan}

1. Hipotesis 1 : Ditolak

Hasil pengolahan data pada perusahaan yang melakukan manajemen laba (sub sampel earnings management) tidak terbukti melakukan rekayasa biaya (expense stickiness) melalui penurunan beban. Bahkan hasil menunjukkan bahwa yang terjadi adalah meningkatnya expense stickiness. Kesimpulan ini sekaligus membutuhkan telaah lebih 
lanjut tentang adanya real earnings management. Manajemen laba lebih sering dilihat sebgai usaha rekayasa akrual sementara itu real earnings management lebih mengarah kepada manipulasi aktivitas riil dan lebih sulit untuk ditemukan karena dilakukan di sepanjang periode.

\section{2, Hipotesis 2: Diterima}

Temuan dari uji hipotesis 2 menunjukkan bahwa good corporate governance, terbukti menunjukkan kecenderungan mampu menurunkan expense stickiness. Kesimpulan ini berdasarkan pengaruh variable utama $G C G$ yang dapat dirasakan untuk bersentuhan dengan kebijakan operasional perusahaan, yaitu peran dari jumlah rapat dewan komisaris dan penentuan proporsi komisaris independen yang tepat. Sehingga dapat disimpulkan bahwa penurunan biaya adalah sebagai hasil dari efektifitas pelaksanaan monitoring good corporate governance saat aktivitas perusahaan menurun.

\subsection{Keterbatasan}

Dalam proses penulisan peneliti dihadapkan pada beberapa keterbatasan dan kendala yang diharapkan tidak terjadi pada penelitian selanjutnya.

1. Periode waktu yang digunakan dalam penelitian ini hanya 2 periode dengan pemikiran bahwa manajemen laba akan berbeda tiap tahun. Penelitian Shuang Xue dan Yung Hong, (2015) menggunakan periode waktu selama 8 tahun.

2. Nilai koefisien determinasi yang belum sempurna menjelaskan sepenuhnya factor-faktor yang mempengaruhi variabel dependen yaitu expense stickiness

\subsection{Saran}

Berdasarkan hasil kesimpulan tersebut terdapat beberapa hal yang perlu dipertimbangkan untuk penelitian lebih lanjut. Penggunaan data dari dua periode waktu sehingga perlu untuk mengembangkan hasil melalui pengambilan data dari beberapa peridode akuntansi. Selain itu penelitian ini bisa dilengkapi dengan mempertimbangkan pengaruh real earnings management terhadap expense stickiness.

\subsection{Implikasi Penelitian}

Implikasi atas simpulan tersebut adalah terhadap efektivitas informasi yang diperoleh pengguna laporan keuangan yang selama ini hanya berfokus pada laporan keuangan pada akhir periode. Dengan tidak ditemukannya usaha-usaha manajemen laba melalui beban akrual maka pengambil putusan perlu mengkaji lebih lanjut tentang kemungkinan adanya variasi manejemen laba yang lain. Hasil temuan yang berdasarkan laporan akhir tahun ini juga menunjukkan bahwa pengambil patusan tidak bisa hanya mengandalkan informasi keuangan pada akhir periode saja, yang mana diduga telah diantisipasi oleh manajemen sehingga tidak nampak adanya usaha manajemen laba.

Terkait dengan $G C G$ yang terbukti berjalan efektif tentunya semakin meyakinkan bahwa perusahaan harus menerapkan dan menjalankannya secara tertib khusunya terhadap konsistensi rapat dewan komisaris dan penentuan proporsi dewan komisaris independen yang tepat. Sebagai pengambil putusan, dapat menggunakan informasi pelaksanaan $G C G$ sebagai pertimbangan dalam menilai kewajaran pengelolaan aktivitas yang dilakukan para manajer, sekaligus menilai keberlajutan perusahaan. 


\section{REFERENSI}

Anderson, M., Banker, R., Janakiraman, S., 2003. Are selling, general, and administrative costs 'sticky'? J. Acc. Res. 41, 47-63. https://doi.org/10.1111/1475-679X.00095

Burgstahler, D., Dichev, I., 1997. Earnings management to avoid losses and earnings decreases. J. Acc. Econ. 24, 99-126. https://doi.org/10.1016/S0165-4101(97)00017-7

Carslaw, C.A.P.N., 1988. Anomalies in income numbers: Evidence of goal oriented behavior. The Accounting Review (April) 321-327. https://www.jstor.org/stable/248109

Cohen,D.,Dey,A.,Lys,T.,2008.Real and accrual-based earnings management in the preandpost-sarbanes oxley periods.Acc.Rev.82,757-787. https://doi.org/10.2308/accr.2008.83.3.757

Cooper, R., Haltiwanger, J., 2006. On the nature of capital adjustment costs. Rev. Econ. Stud. 73, 611-633. https://doi.org/10.1111/j.1467-937X.2006.00389.x

Cooper,R.,Kaplan,R.,1998. The Design of Cost Management Systems: Text, Cases, and Readings. Prentice-Hall, Upper Saddle River, NJ.

Degeorge, F., Patel, J., Zeckhauser, R., 1999. Earnings management to exceed thresholds. J. Bus. 72, 1-33. https://doi.org/10.1086/209601

Dierynck,B., Renders, A. 2009. The Influence of Earnings Management Incentives on the Asymmetric Behavior of Labor Costs: Evidence from a Non-US Setting.Working Paper,Katholieke Universitet Leuven.

FCGI. 2001. Peranan Dewan Komisaris dan Komite Audit dalam Pelaksanaan Corporate Governance (Tata Kelola Perusahaan). Jilid II, Edisi 2.

Goux, D., Maurin, E., Pauchet, M., 2001. Fixed-term contracts and the dynamics of labor demand. Eur. Econ. Rev. 45, 533-552. https://doi.org/10.1016/S0014-2921(00)00061-1

Jaramillo, F., Schiantarelli, F., Sembenelli, A, 1993. Are adjustment costs for labor asymmetric? An econometric test on panel data forItaly. Rev. Econ. Stat. 74, 640-648. https://doi.org/10.2307/2110017

Jensen, M. C and Meckling, W. H. 1976. Theory of the firm: Managerial behavior, agency costs and ownership structure. Journal of financial economics, 3(4), 305-360, https://doi.org/10.1016/0304-405X(76)90026-X

Kama, I., Weiss D. 2010. Do Managers' Deliberate Decisions Induce Sticky Costs? Working Paper, Tel Aviv University.

Muntoro, R. 2011. Membangun Dewan Komisaris Yang Efektif.

Noreen,E.,Soderstrom,N.,1997.The accuracy of proportional cost models:evidence from hospital service departments.Rev.Acc.Stud.2, 89-114. https://doi.org/10.1023/A:1018325711417

Pfann,G.,Palm,F.,1993.Asymmetric adjustment costs in non-linear labour demand models for the Netherlands and UK manufacturing sectors. Rev. Econ. Stud. 60,397-412. https://doi.org/10.2307/2298064

Pfann, G., Palm, F., 1997. Sources of asymmetry in production factor dynamics. J. Econ. 82, 361-392. https://doi.org/10.1016/S0304-4076(97)00078-X

Roychowdhury, S., 2006. Earnings management through real activities manipulation. J. Acc. Econ. 41, 335-370. https://doi.org/10.1016/j.jacceco.2006.01.002

Scott, William R. 2015. Financial Accounting Theory.Canada : Prentice Hall Inc. 
Sulistiawan, D., Januarsi, Y., dan Alvia, L. 2011. Creative Accounting, Mengungkap Manajemen Laba dan Akuntansi. Jakarta: Salemba Empat

Wardhani, R. dan Joseph, H. 2010. Karakteristik Pribadi Komite Audit Dan Praktik Manajemen Laba. SNA 13 Purwokerto. AKPM 38.

Xue, S., Hong, Y. Earning Management, corporate governance, and expense stickiness.China Journal of Accounting Research, 9(1), 41-58. https://doi.org/10.1016/j.cjar.2015.02.001 